Оригинальные статьи / Original articles

https://doi.org/10.18619/2072-9146-2021-5-89-97 УДК 631.811.98-047.37:635.652/.654

Е.Г. Козарь ', И.А. Енгалычева ${ }^{1}$ А.А. Антошкин ${ }^{1}$, Н.Е. Мащенко

${ }^{1}$ Федеральное государственное бюджетное научное учреждение "Федеральный научный центр овощеводства" (ФГБНУ ФНЦО)

143072, Россия, Московская область,

ОдинцОвский район,

п. ВНИИССОК, ул. Селекционная, д.14

${ }^{2}$ Институт генетики, физиологии и защиты растений АНМ

ул. Падурии, 20

Кишинев, MD 2002

Конфликт интересов. Авторы заявляют об отсутствии конфликта интересов.

Вклад авторов: Все авторы участвовали в планировании и постановке эксперимента, а также в анализе экспериментальный данных и написании статьи.

Для цитирования: Козарь Е.Г., Енгалычева И.А., Антошкин А.А., Мащенко Н.Е. Боровская А.Д. Скрининг биологической активности фитопрепаратов на основе вторичных метаболитов растений на культуре Phaseolus vulgaris. Овощи России. 2021;(5):89 97. https://doi.org/10.18619/2072-9146-2021-589-97

Поступила в редакцию: 25.09.2021

Принята к печати: 05.10.2021

Опубликована: 11.10.2021
Скрининг биологической активности фитопрепаратов на основе вторичных метаболитов растений на культуре Phaseolus vulgaris

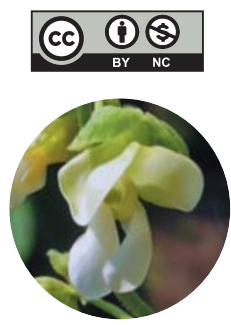

Резюме

Актуальность. В настоящее время использование вторичных метаболитов растительного происхождения с высокой биологической активностью становится важной составной частью комплексной программы защиты растений. Механизм их действия направлен на активацию молекулярно-биологических и физиологических систем, повышающих способность растительного организма противостоять неблагоприятным воздействиям биотической и абиотической природы. Цель данных исследований - скрининг избирательности физиологической активности фиторегуляторов в отношении разных сортов культуры фасоли овощной.

Методика. Растения двух среднеспелых сортов фасоли овощной двукратно опрыскивали растворами растительных биопрепаратов различного химического состава, выделенных из 12 видов растений различных семейств. Контроль - обработка водой, стандарты - растворами Фармайода и Фитолавина. В период вегетации проводили анализ развития болезней раз личной этиологии на семеноводческих посевах. Семенную продуктивность растений учитывали после уборки и обмолота бобов, посевные качества полученных семян изучали согласно соответствующим рекомендациям и ГОСТ $12042-80$ и рассчитывали биологическую эффективность (БЭ) действия фиторпрепаратов.

Результаты. Двукратная обработка растений фасоли большинством испытанных препаратов снизила общий процент пораженных растений более чем на 25\%. Защитное действие изу ченных гликозидов существенно различалось в зависимости от их химического строения, этиологии болезни и отзывчивости сорта. Среди них выделяются препараты на основе стероидных гликозидов -Молдстим и Местим, обладающие наиболее выраженным иммуномодулирующим действием на устойчивость растений фасоли овощной к фитопатогенам. Обработка Местимом в выбранной концентрации привела к снижению семенной продуктивности растений. Другие фитопрепараты проявили нейтральное или стимулирующее действие на этот признак, повышая долю всхожих семян в структуре урожая на 3-26\% относительно контроля. По совокупной эффективности действия вывялена определенная сортовая специфика. На отзывчивом сорте Лика наибольшую активность проявили ириоидные гликозиды из Linaria genistifolia и сумма иридоидов и флавоноидов из Linaria vulgaris. Hа сорте СиБемоль - стероидный гликозид фуростанолового ряда Молдстим, выделенный из Capsicum annuum. Их биологическая эффективность была выше, чем у стандартов Фитолавина и Фармайода.

Ключевые слова: фасоль овощная, вторичные метаболиты, стероидные гликозиды, фитопатогены, скрининг.
Elena G. Kozar', Irina A. Engalycheva', Alexandr A. Antoshkin',

Natalia E. Mashcenco ${ }^{2}$

'Federal State Budgetary Scientific Institution Federal Scientific Vegetable Center (FSBSI FSVC) 14 , Selectsionnaya str., VNIIISOK, Odintsovo district, Moscow region, Russia, 143072

${ }^{2}$ Institute of Genetics, Physiology and Plant Protection, Republic of Moldova 20, str. Padurii, Chisinau, Republic of Moldova 2002

Conflict of interest. The authors declare no conflict of interest.

Authors' Contribution: All authors contributed to the planning and setting up the experiment, as well as in the analysis of experimental data and writing of the article.

For citations: Kozar E.G., Engalycheva I.A., Antoshkin A.A., Mashcenco N.E. Screening of biological activity of phytopreparations based on secondary metabolites of plants on the culture of Phaseolus vulgaris. Vegetable crops of Russia. 2021;(5):89-97. (In Russ.) https://doi.org/10.18619/2072-9146-2021-5-8997

Received: 25.09.2021

Accepted for publication: 05.10.2021

Accepted: 11.10.2021

\section{Screening of biological activity of phytopreparations based on secondary metabolites of plants on the culture of Phaseolus vulgaris}

\section{Abstract}

Relevance. Currently, the use of secondary plant-orgin metabolites with high biological activity is becoming an important part of a comprehensive plant protection program. The mechanism of their action is aimed at activating molecular biological and physiological systems that increase the ability of the plant organism to withstand the adverse effects of biotic and abiotic nature. The purpose of these studies is to screen the selectivity of the physiological activity of phytoregulators in relation to different varieties of vegetable beans.

Methodology. Plants of two mid-ripening varieties of vegetable beans were twice sprayed with solutions of plant biological products of different chemical composition, isolated from 12 plant species of different families. Control - treatment with water, standards - solutions of Pharmayod and Fitolavin. During the growing season, an analysis of the development of diseases of various etiologies on seed crops was carried out. Seed productivity of plants was taken into account after harvesting and threshing the beans, the sowing qualities of the obtained seeds were studied in accordance with the relevant recommendations and GOST 12042-80, and the biological effectiveness (BE) of the action of phytopreparations was calculated.

Results. Two-fold treatment of beans with most of the tested preparations reduced the total percentage of affected plants by more than $25 \%$. The protective effect of the studied glycosides differed significantly depending on their chemical structure, disease etiology and cultivar responsiveness. Among them, there are preparations based on steroidal glycosides - Moldstim and Mestim, which have the most pronounced immunomodulatory effect on the resistance of vegetable beans to phytopathogens. Treatment with Mestim in the selected concentration led to a decrease in seed productivity of plants. Other phytopreparations showed a neutral or stimulating effect on this trait, increasing the proportion of germinating seeds in the yield structure by $3-26 \%$ relative to control. The certain varietal specificity has been identified by the total effectiveness of the action. Irioid glycosides from Linaria genistifolia and the sum of iridoids and flavonoids from Linaria vulgaris showed the greatest activity on the responsive cultivar Lika. On the SiBemol variety, there is Moldstim, a steroidal glycoside of the furostanol series, isolated from Capsicum annuum. Their biological effectiveness was higher than that of Fitolavin and Pharmayod standards.

Keywords: vegetable bean, secondary metabolites, steroid glycosides, phytopathogens, screening 
$\Phi$ асоль обыкновенная (Phaseolus vulgaris L.) является важной продовольственной культурой во многих странах мира. По данным ФАО, в настоящее время общемировой валовой сбор бобов фасоли овощной (green beans) составляет в среднем около 25 млн т, площадь выращивания - 1,6 млн га. Валовый сбор зерна фасоли обыкновенной (dry beans) - более 30 млн т, площадь выращивания - 37 млн га [1-3]. По данным «Всероссийской сельскохозяйственной переписи», общая посевная площадь под культурой фасоли овощной в РФ на 2017 год составила около 7 тыс. га, из которых половина - это территория личных подсобных хозяйств (ЛПХ). Валовой сбор зерна фасоли в промышленном секторе в среднем составил около 6 тыс. т, но в последние годы наметилась тенденция активизации его развития $[4,5]$.

Выращивают фасоль для получения недозрелых бобов и семян (зерна) в качестве источника белка и незаменимых аминокислот. В зерне фасоли содержание белка составляет 22-26\%, что в 1,5-2 раза выше, чем у зерновых культур. Продукты из фасоли позволяют не только удовлетворить потребности человека в растительном белке (усваивается организмом человека на 75-85\%), но и разнообразить рацион питания. Высокая пищевая ценность фасоли также обусловлена наличием большого количества витаминов, макро- и микроэлементов, необходимых для функционирования человеческого организма [6-8]. Добавление в рацион овощей, в том числе фасоли, способствует снижению негативного воздействия усиливающейся экологической и социальной нагрузки на человека $[3,8,13]$.

Селекционная работа с бобовыми культурами, в том числе фасоли обыкновенной, в Российской Федерации была начата с момента основания Грибовской овощной селекционной опытной станции (1920 год), ныне ФГБНУ “Федеральный научный центр овощеводства". Достижениями нескольких поколений наших селекционеров является создание промышленных сортов фасоли овощной, пригодных для механизированной уборки со стабильно высокой урожайностью и качеством товарной продукции [9-11]. При этом большое внимание уделяется пластичности создаваемых сортов, что способствует более широкому ареалу их районирования в различных по агроклиматическим условиям регионах РФ $[11,12]$. В последние годы активно создаются сорта фасоли спаржевого типа для личных приусадебных хозяйств (ЛПХ), которые обладают растянутым периодом получения свежих молодых бобов $[9,11]$. На сегодняшний день из 141 сорта фасоли овощной, включенных в Государственный реестр селекционных достижений, допущенных к использованию, 45 сортов, т.е. 32\% - это сорта селекции центра [14].

Phaseolus vulgaris является теплолюбивой культурой, в связи с чем для ее продвижения в более северные регионы (Центральный, Нечерноземный, ЗападноСибирский и другие) ранее основное внимание уделяли скороспелости сорта, но в последние десятилетия на фоне изменений климата тенденции несколько изменились. Стали востребованы сорта более поздних сроков созревания (среднеранние и среднеспелые), продуктивный потенциал растений которых, как правило, выше, чем у скороспелых сортов [9, 15, 16, 17]. Однако получение высоких и устойчивых урожаев семян фасоли овощной в зонах рискованного земледелия ограничивается целым рядом абиотических и биотических факторов среды.

Одна из проблем, с которой сталкиваются семеноводы-оригинаторы - это нестабильность погодных условий. В неблагоприятные для развития растений фасоли годы процесс формирования семян значительно замедляется, и требуется их послеуборочное дозаривание перед обмолотом, особенно у сортов более поздних сроков созревания. Это негативно влияет на посевные качества и приводит к увеличению доли невыполненных «щуплых» семян в общей массе. Кроме того, общая тенденция потепления климата приводит к появлению ранее редко встречающихся в данных регионах болезней и повышению вредоносности аборигенных возбудителей [18, 19].

По результатам многолетнего мониторинга в условиях Московской области, помимо бактериозов (возбудители Pseudomonas syringae pv. phaseolicola, Pseudomonas syringae pv. syringae, Xanthomonas axonopodis pv. phaseoli (Smith) Vauterin et al., Pantoea ssp.), нарастает интенсивность распространения агрессивных видов рода Fusarium (F. solani f. sp. phaseoli; F.oxysporum v. oxysporum; F.oxysporum v. artroceras; F. semitectum; F. javanicum и др.), вируса обыкновенной мозаики фасоли (Bean common mosaic potyvirus) и вируса желтой мозаики фасоли (Bean yellow mosaic potyvirus), развитие которых в отдельные годы достигает эпифитотийного уровня [20-23]. Изменение фитопатологической обстановки влияет не только на продуктивность и товарное качество продукции востребованных сортов фасоли, но и создает ряд проблем при ведении их первичного семеноводства, поскольку многие возбудители могут поражать семена, существенно снижая их посевные качества.

В настоящее время в технологии возделывания ряда сельскохозяйственных культур особое место занимают биологически активные вещества (БАВ) гормонального и негормонального типа природного происхождения [24-26]. В результате многолетних исследований биологической активности вторичных метаболитов высших растений (стероидные гликозиды, иридоиды и флавоноиды), выделенных в индивидуальном или суммарном в виде из представителей различных семейств, удалось установить, что они представляют большой интерес для повышения стрессоустойчивости растений. Действие этих соединений, в первую очередь, направлено на активацию молекулярно-биологических и физиологических систем, интенсификацию общего и гормонального обмена растений, обеспечивающих защиту от патогенов и неблагоприятных воздействий абиотической природы, путем образования эндогенных веществ различной природы [27-31]. Использование таких биорегуляторов позволяет существенно сократить применение синтетических пестицидов, которые вместе с токсическим действием на фитопатогенные микроорганизмы оказывают отрицательное влияние и на полезную микробиоту, существенно загрязняют окружающую среду, накапливаясь в почве и растительных остатках, приводят к появлению новых резистентных рас возбудителей [32].

Широкое применение препаратов на основе вторичных метаболитов растений тормозит недостаточная 
изученность механизмов их регуляторного влияния с учетом биологических особенностей культур и высокой избирательности действия разных по химической структуре БАВов. Поэтому в основном используется эмпирический подход к их выбору и использованию на различных видах растений. В связи с вышеизложенным, целью настоящей работы являлся скрининг биологической эффективности действия препаратов на основе вторичных метаболитов, выделенных из представителей семейств Solonaceae, Scrophulariaceae, на пораженность болезнями и семенную продуктивность растений, структуру и посевные качества семян фасоли овощной.

\section{Материалы и методы}

В эксперименте использовали как официнальные фитопрепараты Экостим, Молдстим и Местим, действующим началом которых являются индивидуальные стероидные гликозиды фуростаноловой природы томатозид, капсикозид и мелонгозид соответственно, а также суммарные препараты биологически активных веществ, полученные на основе вторичных метаболитов некоторых представителей дикорастущей флоры (табл.1). Источником получения томатозида служили семена Solanum lycopersicum, мелонгозида - семена Solánum melongéna, а капсикозида - семена Capsicum annum. Из надземной части растений Verbascum densiflorum, Melampyrum nemorosum, Scrophularia nodosa, Linaria vulgaris, Linaria genistifolia, Veronica officinale Veronica spuria, Veronica teucrium и Veronica spicata были получены суммарные очищенные экстракты биологически активных веществ (БАВы), содержащие главным образом иридоидные и фенольные соединения. Суммарные экстракты из указанных растительных источников были выделены методом исчерпывающей экстракции водным этанолом при нагревании на водяной бане с последующей очисткой адсорбционно-распределительной хроматографией на колонках с силикагелем и полиамидом. Контроль за разделением осуществляли методом тонкослойной хроматографии с помощью специфических проявителей [33-37].

Тестирование активности гликозидов проводили двух сортах фасоли овощной Лика и Си Бемоль селекции ФГБНУ ФНЦО:
Лика - среднеспелый сахарный. Растение кустовое, высотой 35-40 см. Бобы прямые, длиной 16-17 см, узкие, без пергаментного слоя и волокна. Высота прикрепления нижних бобов 16-20 см. Вкусовые качества продукции отличные. Урожайность бобов 16-19 т/га. Рекомендуется для консервирования и замораживания. Сорт пластичный, переносит засуху и переувлажнение, устойчив к пониженным положительным температурам. Семена эллиптической формы, охряные, масса 1000 семян 290-300 г. Урожайность семян 2,63,2 т/га. Включен в Госреестр по Российской Федерации для промышленного возделывания в 2006 году.

Си Бемоль - среднеспелый сорт, универсального использования. Рекомендуется для использования в кулинарии и консервирования. Растение кустовое, длина стебля - 40-50 см. Листья зеленые, крупные, морщинистые. Цветки мелкие, белые. Бобы в технической спелости светло-зеленые, слабоизогнутые, без пергаментного слоя и волокна, длина 9-15 см, ширина 1,0-1,4 см, форма на поперечном сечении от эллиптического до яйцевидного, клювик средней длины. Высота прикрепления нижних бобов 15-18 см. Масса 100 бобов 580-620 г. Вкусовые качества продукции хорошие. Характеризуется относительной устойчивостью к антракнозу и корневой гнили. Семена эллиптические, красные, жилкование слабое. Товарная урожайность бобов - 15,0-16,5 т/га. Включен в Госреестр по Российской Федерации для выращивания в ЛПХ в 2019 году.

Опыты закладывали на семеноводческих посевах лаборатории селекции и семеноводства бобовых культур ФГБНУ ФНЦО (Московская область). Технология выращивания - рекомендованная для Нечерноземной

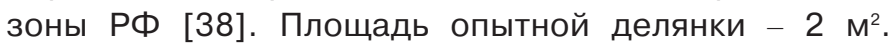
Повторность 3-кратная. Размещение систематическое. Число учетных растений 40-45 шт. на делянке в зависимости от сорта. Посев механизированный, сеялками точного высева. Перед посевом семена протравливали контактным фунгицидом ТМТД, ВСК (д.в. Тирам - 400 г/л) из расчета 7 л/т (с нормой расхода рабочего раствора 10 л/т согласно инструкции производителя), в период вегетации также проводили однократное внесение гербицида Базагран из расчета 3 л/га.

Таблица 1. Характеристика растительных биологически активных фитопрепаратов Table 1. Characteristics of herbal biologically active phytopreparations

\begin{tabular}{|c|c|c|c|}
\hline $\begin{array}{c}\text { Краткое } \\
\text { обозначение }\end{array}$ & $\begin{array}{l}\text { Название } \\
\text { препарата }\end{array}$ & $\begin{array}{l}\text { Источник получения } \\
\text { (вид растения) }\end{array}$ & $\begin{array}{c}\text { Основной тип БАВов } \\
\text { составе препарата }\end{array}$ \\
\hline V1 & вероофицилизид & Veronica officinalis & $\Sigma$ фллавоноидов и иридоидов \\
\hline V2 & вероспруризид & Veronica spicata & $\Sigma$ флавоноидов и иридоидов \\
\hline V3 & вероспикатизид & Veronica spuria & $\sum$ флавоноидов (max) и иридоидов \\
\hline V4 & веротеокризид & Veronica teucrium & $\sum$ флавоноидов, иридоидов и сапонинов \\
\hline $\operatorname{Lg}$ & генистифализид & Linaria genistifolia & $\sum$ ириоидных гликозидов \\
\hline Lv & линарозид & Linaria vulgaris & $\sum$ ириоидных и фрлавоноидных гликозидов \\
\hline Sn & скрофруларизид & Scrophularia nodosa & $\sum$ фрлавоноидов \\
\hline Mn & меланпирозид & Melampyrum петorosum & $\Sigma$ флавоноидов и иридоидов \\
\hline Vd & вербаскозид & Verbascum densiflorum & $\sum$ иридоидов и фллавоноидов \\
\hline Md & молдстим & Capsicum annum & Стероидный фруростаноловый гликозид капсикозид \\
\hline Me & местим & Solanum melongena & Стероидный фуростаноловый гликозид мелонгозид \\
\hline Эк & эКОстим & Solanum lycopersicum & Стероидный фуростаноловый гликозид томатозид \\
\hline
\end{tabular}


Обработки проводили путем опрыскивания растений растворами БАВов с помощью ручных пульверизаторов двукратно: 1 обработка - фаза 5-6 настоящих листьев в концентрации 0,001\%; 2 обработка - фаза цветения и начала завязывания плодов, концентрация гликозидов 0,01\%. В качестве стандартов сравнения использовали рекомендованные на бобовых культурах препараты:

- биопрепарат Фитолавин с концентрацией действующего вещества фитобактериомицина БА-120000 ЕА/мл, 32 г/л; опрыскивание растений проводили 0,2\% рабочим раствором, производитель НПЦ «Фармбиомед». Обладает бактерицидным, фунгицидным и ростостимулирующим эффектом. Расход рабочей жидкости - 30 л/га.

- препарат Фармайод, ГР (100 г/л йод-12), опрыскивание растений проводили 0,05\% раствором, производитель НПЦ «Фармбиомед» Обладает противовирусным, бактерицидным (кроме инфекций, вызываемых спорообразующими бактериями и микобактериями), фунгицидным эффектом. Расход рабочей жидкости 30 л/га.

Учеты поражения болезнями проводили в фазу начала технической спелости бобов. Визуально оценивали распространенность болезней (Р\%); индекс поражения растений по четырехбалльной шкале; рассчитывали степень развития болезни (R\%) по общепринятым методикам [40-41]. Уборку и обмолот растений в фазе биологической спелости семян проводили вручную. Общую массу полученных семян с каждой опытной делянки, массу 1000 семян и их посевные качества определяли в соответствии с ГОСТом [42, 43]. При изучении структуры семенного материала выделяли следующие основные фракции: всхожие, невыполненные, больные с внешними признаками поражения и с внутренним инфицированием патогенами (выявляли при проращивании внешне здоровых семян), семена в глубоком покое (не прорастающие и без признаков поражения).

Обработку данных проводили по соответствующим методам статистического анализа с использованием программ LightCycler® 480 SW 1.5.1 и MS EXEL 2010.

\section{Результаты и обсуждение}

Фитопатологический мониторинг семеноводческих посевов изучаемых сортов фасоли овощной выявил, что естественный инфекционный фон в период проведения исследований характеризовался средним уровнем напряженности при достаточно высокой общей распространенности болезней. Суммарная доля пораженных растений в контроле на начало технической спелости бобов составила 68\% (Си Бемоль) и 90\% (Лика).

Среди всего комплекса отмеченных симптомов наиболее распространены были болезни бактериальной и вирусной этиологии (бурый и угловатый бактериозы, вирус обыкновенной мозаики фасоли - ВОМФ), а также некроз жилок, вызванный смешанной инфекцией. Среди микозов наиболее значимое развитие получил фузариоз в виде корневых гнилей, хлороза нижних листьев и увядания растений. Признаки поражения альтернариозом и антракнозоми встречались на единичных растениях.

Как видно из таблицы 2, сорта отличались в большей степени по распространенности (Р\%) основных болезней, чем по среднему индексу поражения (I, балл). В целом по совокупному показателю степени развития болезней (R\%) сорт Лика был более восприимчив к бактериозам, некрозу жилок и фузариозу, а сорт Си Бемоль (СБМ) - к ВОМФ.

Влияние вторичных метаболитов высших растений на устойчивость растений к болезням. Двукратная обработка растений большинством испытанных БАВов оказала положительное действие на устойчивость растений, а именно существенно снизился общий процент пораженных растений (> 25\%), который в среднем по всем вариантам обработок составил $42 \%$ (Си Бемоль) и 54\% (Лика). При этом корреляционный анализ выявил среднюю положительную взаимосвязь между величиной биологической эффективности (БЭ) действия биорегуляторов и средним индексом поражения растений разными возбудителями в контроле $(r=0,41)$ (рис. 1Б).

В среднем биологическая эффективность БАВов на обоих сортах была сравнима и более выражена в отношении ВОМФ (БЭ $\approx 80 \%$ ), несколько ниже - при поражении бактериозами бобов (БЭ $60 \%)$ и листьев (БЭ $245 \%$ ). Величина положительных эффектов действия фитопрепаратов на степень развития некроза жилок и фузариоза у сортов отличалась. В первом случае их общая эффективность в среднем была выше у более восприимчивого сорта Лика (БЭ $50 \%$ ), во втором - у более устойчивого сорта Си Бемоль (БЭ $70 \%)$ (рис.1A).

Таблица 2. Степень поражения сортов фасоли овощной болезнями различной этиологии в условиях Московской области (контроль, 2018-2019 годы)

Table 2. The degree of damage to bean varieties with vegetable diseases of various etiologies in the conditions of the Moscow region (control, 2018-2019)

\begin{tabular}{|c|c|c|c|c|c|c|c|}
\hline \multirow{2}{*}{ Болезнь } & \multicolumn{3}{|c|}{ Лика } & \multicolumn{3}{|c|}{ Си Бемоль } & \multirow{2}{*}{ HCP05 (R\%) } \\
\hline & $\mathrm{P} \%$ & I, балл & $\mathrm{R} \%$ & $\mathrm{P} \%$ & I, балл & $\mathrm{R} \%$ & \\
\hline ВОМФ & 13,8 & 0,90 & 4,6 & 17,4 & 1,29 & 7,8 & 1,8 \\
\hline Некроз жилок & 41,7 & 1,18 & 15,2 & 12,5 & 0,46 & 4,5 & 3,3 \\
\hline Бактериозы (листья) & 30,8 & 1,06 & 9,7 & 22,5 & 1,03 & 7,1 & 1,7 \\
\hline Бактериозы (бобы) & 9,2 & 0,40 & 3,6 & 5,0 & 0,32 & 1,2 & 0,9 \\
\hline Фузариоз & 17,5 & 0,71 & 6,1 & 15,0 & 0,78 & 4,3 & 1,3 \\
\hline
\end{tabular}




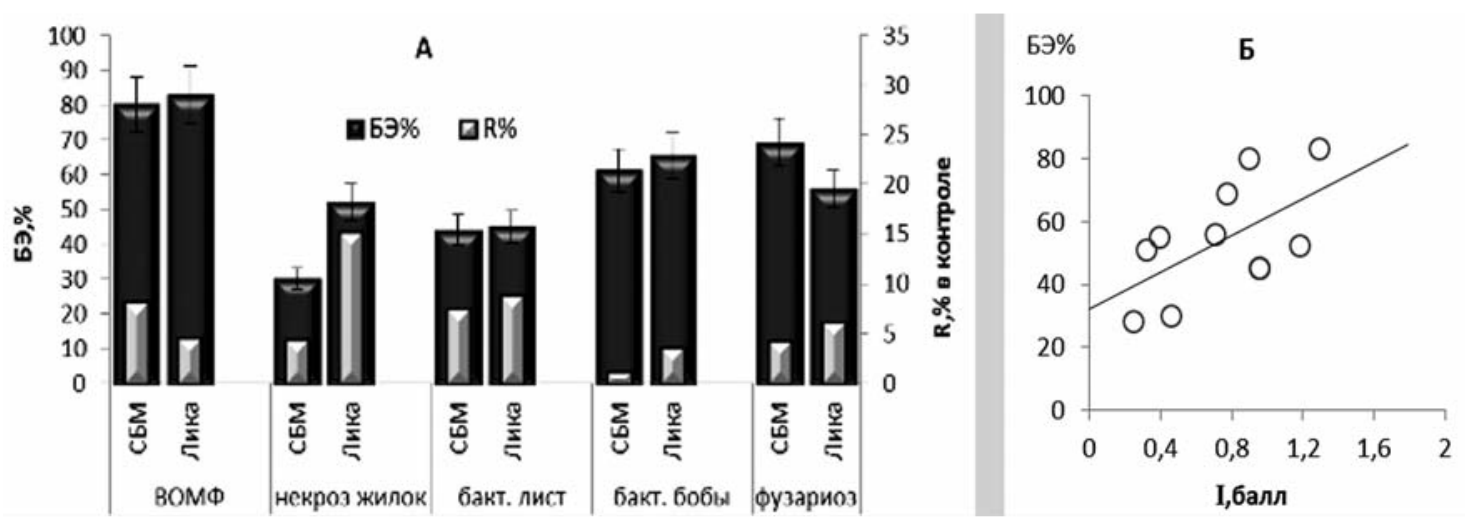

Рис.1. Биологическая эффективность действия фитопрепаратов по снижению показателя степени развития болезнями сортов фасоли овощной относительно контроля (А) и ее взаимосвязь с индексом поражения растений (Б). Усредненные данные по всей совокупности испытанных препаратов

Однако, несмотря на выявленные общие тенденции, иммуномодулирующее действие разных фитопрепаратов существенно различалось в зависимости от происхождения и химического строения, этиологии болезни и отзывчивости сорта. Коэффициенты варьирования по величине БЭ отдельных БАВов составили CV $=29-61 \%$ - у сорта Лика и CV=37-128\% - у сорта Си Бемоль (табл.3).

В отношении ВОМФ высокую биологическую активность (БЭ=91-100\%) на уровне фармайода (FJ) на обоих сортах проявили препараты: веротеокризид (V4) и экостим (Эк), а на уровне фитолавина (FL) - вероспруризид (V2), генистифализид ( $\mathrm{gg})$, молдстим (Md) и местим (Me). Снижение развития бактериозов и некроза жилок под влиянием испытанных препаратов, как и стандартов, имеет выраженную сортовую специфику. По эффективности снижения пораженности листовыми пятнистостями в данном случае можно выделить линарозид (Lv) и вербаскозид (Vd), а поражения зеленых бобов - веротеокризид, молдстим и местим, эффектив- ность которых на обоих сортах была сравнима с фитолавином. Развитие некроза жилок более значимо сдерживали препараты местим и меланпирозид (Mn) (БЭ=67-91\%), причем на сорте Лика их активность была выше, чем у фитолавина. По влиянию на устойчивость растений к фузариозу большинство БАВов превысило активность стандартов, причем самая высокая БЭ (>70\%) на обоих сортах отмечена у препаратов: вероспруризид, генистифализид, молдстим и местим (табл.3). Отмеченная высокая активность действия большинства испытуемых препаратов в отношении отдельных болезней, по-видимому, объясняется относительно невысокой интенсивностью их развития в условиях открытого грунта Московской области в период исследований.

Влияние БАВов на семенную продуктивность растений, структуру и качество семенного потомства. В наших исследованиях обработка растений сорта Лика водными растворами природных биорегуляторов оказала положительное действие на семенную

Таблица 3. Биологическая эффективность действия БАВов на степень развития болезней на сортах фасоли овощной (отклонение относительно контроля, \%)

Table 3. Biological effectiveness of the action of biologically active substances on the degree of development of diseases on varieties of vegetable beans (deviation relative to control, \%)

\begin{tabular}{|c|c|c|c|c|c|c|c|c|c|c|c|c|c|c|c|}
\hline \multirow{2}{*}{ Препарат } & \multicolumn{3}{|c|}{ ВОМФ } & \multicolumn{3}{|c|}{ Некроз жилок } & \multicolumn{3}{|c|}{ Бактериозы (листья) } & \multicolumn{3}{|c|}{ Бактериозы (бобы) } & \multicolumn{3}{|c|}{ Фузариоз } \\
\hline & Лика & СБМ & $\mathrm{cp}$ & Лика & СБМ & $\mathbf{c p}$ & Лика & СБМ & $\mathbf{c p}$ & Лика & СБМ & $\mathbf{c p}$ & Лика & СБМ & $\mathrm{cp}$ \\
\hline FL & 100 & 82 & 91 & 47 & 97 & 72 & 63 & 71 & 67 & 100 & 100 & 100 & 12 & 63 & 38 \\
\hline FJ & 100 & 100 & 100 & 0 & 0 & 0 & 95 & 25 & 60 & 100 & 0 & 50 & 32 & 63 & 47 \\
\hline V1 & 42 & 77 & 60 & 34 & 53 & 44 & 48 & 95 & 71 & 31 & 100 & 66 & 0 & 29 & 14 \\
\hline V2 & 100 & 94 & 97 & 56 & 0 & 28 & 44 & 0 & 22 & 54 & 0 & 27 & 86 & 100 & 93 \\
\hline V3 & 80 & 30 & 55 & 67 & 0 & 34 & 26 & 11 & 18 & 0 & 14 & 7 & 34 & 88 & 61 \\
\hline V4 & 100 & 100 & 100 & 40 & 0 & 20 & 27 & 78 & 53 & 100 & 100 & 100 & 73 & 5 & 39 \\
\hline $\mathrm{Lg}$ & 100 & 87 & 94 & 73 & 26 & 49 & 76 & 34 & 55 & 91 & 48 & 70 & 100 & 74 & 87 \\
\hline Lv & 69 & 9 & 39 & 27 & 0 & 14 & 88 & 62 & 75 & 100 & 0 & 50 & 86 & 0 & 43 \\
\hline Sn & 41 & 97 & 69 & 84 & 0 & 42 & 44 & 31 & 38 & 77 & 31 & 54 & 59 & 42 & 51 \\
\hline$M n$ & 55 & 100 & 77 & 78 & 85 & 82 & 26 & 17 & 21 & 100 & 45 & 72 & 39 & 95 & 67 \\
\hline Vd & 95 & 77 & 86 & 19 & 81 & 50 & 60 & 70 & 65 & 31 & 66 & 48 & 46 & 90 & 68 \\
\hline Md & 100 & 91 & 96 & 33 & 0 & 16 & 37 & 34 & 35 & 99 & 100 & 100 & 76 & 88 & 82 \\
\hline $\mathrm{Me}$ & 100 & 91 & 95 & 67 & 91 & 79 & 46 & 41 & 43 & 99 & 100 & 100 & 73 & 100 & 86 \\
\hline Эк & 100 & 100 & 100 & 48 & 17 & 32 & 13 & 69 & 41 & 0 & 100 & 50 & 0 & 100 & 50 \\
\hline V\% & 29 & 37 & & 41 & 128 & & 49 & 65 & & 61 & 70 & & 59 & 56 & \\
\hline
\end{tabular}


Таблица 4. Биологическая эффективность действия обработок фитопрепаратами на семенную продуктивность растений и массу 1000 семян среднеспелых сортов фасоли овощной

Table 4. Biological efficiency of the action of treatments with phytopreparations on the seed productivity of plants and the weight of 1000 seeds of mid-season varieties of vegetable beans

\begin{tabular}{|c|c|c|c|c|c|c|c|c|}
\hline \multirow{3}{*}{ Препарат } & \multicolumn{4}{|c|}{ Продуктивность растений } & \multicolumn{4}{|c|}{ М1000 семян } \\
\hline & \multicolumn{2}{|c|}{ Лика } & \multicolumn{2}{|c|}{ Си Бемоль } & \multicolumn{2}{|c|}{ Лика } & \multicolumn{2}{|c|}{ СиБемоль } \\
\hline & г/раст. & БЭ\% & г/раст. & БЭ\% & r & БЭ\% & $r$ & БЭ\% \\
\hline K & 13,0 & & 13,2 & & 331,1 & & 713,4 & \\
\hline FL & 17,9 & 38 & 11,4 & -11 & 346,7 & 4,7 & 680,0 & $-4,7$ \\
\hline FJ & 12,3 & -5 & 10,2 & -22 & 340,0 & 2,7 & 686,7 & $-3,7$ \\
\hline V1 & 13,8 & 6 & 11,5 & -13 & 346,7 & 4,7 & 706,7 & $-0,9$ \\
\hline V2 & 15,0 & 16 & 13,5 & 2 & 356,7 & 7,7 & 726,7 & 1,9 \\
\hline V3 & 14,5 & 12 & 14,6 & 10 & 373,3 & 12,8 & 733,3 & 2,8 \\
\hline V4 & 15,0 & 16 & 12,4 & -6 & 340,0 & 2,7 & 720,0 & 0,9 \\
\hline $\mathrm{Lg}$ & 15,0 & 16 & 12,9 & -2 & 330,0 & $-0,3$ & 693,3 & $-2,8$ \\
\hline Lv & 17,3 & 34 & 11,9 & -10 & 336,7 & 0,7 & 706,7 & $-0,9$ \\
\hline Sn & 15,2 & 17 & 13,3 & 0,5 & 363,3 & 9,7 & 726,7 & 1,9 \\
\hline $\mathrm{Mn}$ & 13,7 & 6 & 17,1 & 30 & 366,7 & 10,7 & 693,3 & $-2,8$ \\
\hline Vd & 12,4 & -3 & 16,7 & 27 & 343,3 & 3,7 & 713,3 & 0,0 \\
\hline Md & 13,4 & 3 & 16,8 & 27 & 366,7 & 10,7 & 773,3 & 8,4 \\
\hline Me & 11,2 & -13 & 13,7 & 4 & 306,7 & $-7,4$ & 746,7 & 4,7 \\
\hline Эк & 11,4 & -12 & 13,3 & 1 & 320,0 & $-3,0$ & 720,0 & 1,0 \\
\hline $\mathrm{HCP}_{05}$ & 1,4 & & 1,0 & & 10,4 & & 10,0 & \\
\hline
\end{tabular}

продуктивность культуры, за исключением местима (табл. 4). Причем, у половины из испытанных препаратов, отмечено достоверное повышение этого показателя относительно контроля (БЭ=12-34\%). Наиболее отзывчив Сорт Лика был на обработку линарозидом (Lv), эффективность действия которого на семенную продуктивность растений была на уровне фитолавина (БЭ=38\%). В то же время в отношении увеличения массы 1000 семян эффективнее оказались вероспикатизид (V3), меланпирозид и молдстим (БЭ>10\%), что в два раза выше по сравнению с фитолавином (БЭ=5\%).

В отличие от сорта Лика, растения сорта Си Бемоль иначе реагировали на обработку изученными препаратами. Достоверное повышение семенной продуктивности у сорта Си Бемоль отмечено в вариантах с примене- нием трех биорегуляторов - молдстим, меланпирозид и вероспикатизид (БЭ=10-30\%), а положительное действие на массу 1000 семян - молдстим и местим (БЭ=58\%). Негативный эффект на семенную продуктивность у данного сорта оказала обработка биологически активными веществами из $V$. officinalis и (V1) и $S$. melongena (Me), равно как и стандартами FL и FJ, которые, в свою очередь, отрицательно повлияли и на массу 1000 семян. Действие остальных БАВов на изменение данных параметров сорта было слабым, и отклонение от контроля в ту или иную сторону статистически было несущественно (табл.4).

Тем не менее, анализ структуры полученного семенного материала выявил положительное действие всех препаратов на посевные качества семян сорта Си

Таблица 5. Влияние фитопрепаратов на структуру урожая семян фасоли овощной Table 5. Influence of phytopreparations on the structure of the yield of vegetable beans

\begin{tabular}{|c|c|c|c|c|c|c|c|c|c|c|c|c|c|c|}
\hline \multirow{4}{*}{ 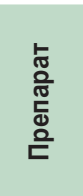 } & \multicolumn{14}{|c|}{ Доля семян в структуре урожая сортов } \\
\hline & \multicolumn{8}{|c|}{ СиБемоль } & \multicolumn{6}{|c|}{ Лика } \\
\hline & \multicolumn{2}{|c|}{ всхожие } & \multicolumn{2}{|c|}{ зараженные } & \multicolumn{2}{|c|}{ невыполненные } & \multicolumn{2}{|c|}{ туго всхожие } & \multicolumn{2}{|c|}{ всхожие } & \multicolumn{2}{|c|}{ зараженные } & \multicolumn{2}{|c|}{ невыполненные } \\
\hline & $\%$ & $\begin{array}{l}\text { Откл. } \\
\text { от K }\end{array}$ & $\%$ & $\begin{array}{l}\text { Откл. } \\
\text { от K }\end{array}$ & $\%$ & $\begin{array}{l}\text { откл. } \\
\text { от К }\end{array}$ & $\%$ & $\begin{array}{l}\text { откл. } \\
\text { от К }\end{array}$ & $\%$ & $\begin{array}{l}\text { Откл. } \\
\text { от К }\end{array}$ & $\%$ & $\begin{array}{l}\text { Откл. } \\
\text { от K }\end{array}$ & $\%$ & $\begin{array}{l}\text { откл. } \\
\text { от К }\end{array}$ \\
\hline К & 55 & & 11 & & 6 & & 28 & & 55 & & 31 & & 14 & \\
\hline FL & 66 & 9 & 18 & 7 & 8 & 2 & 8 & -20 & 81 & 26 & 14 & -17 & 5 & -9 \\
\hline FJ & 87 & 30 & 4 & -7 & 4 & -2 & 4 & -24 & 62 & 7 & 17 & -14 & 21 & 7 \\
\hline V1 & 79 & 22 & 4 & -7 & 9 & 3 & 8 & -20 & 75 & 20 & 19 & -12 & 6 & -8 \\
\hline V2 & 74 & 17 & 10 & -1 & 8 & 2 & 8 & -20 & 62 & 7 & 13 & -18 & 25 & 11 \\
\hline V3 & 86 & 29 & 0 & -11 & 2 & -4 & 12 & -16 & 59 & 4 & 29 & -2 & 11 & -3 \\
\hline V4 & 79 & 22 & 13 & 2 & 3 & -3 & 6 & -22 & 58 & 3 & 22 & -9 & 20 & 6 \\
\hline Lg & 80 & 23 & 4 & -7 & 12 & 6 & 4 & -24 & 80 & 25 & 6 & -25 & 14 & 0 \\
\hline Lv & 70 & 13 & 14 & 3 & 9 & 3 & 6 & -22 & 70 & 15 & 5 & -26 & 25 & 11 \\
\hline Sn & 84 & 27 & 7 & -4 & 2 & -4 & 7 & -21 & 55 & 0 & 20 & -11 & 24 & 10 \\
\hline $\mathrm{Mn}$ & 73 & 16 & 4 & -7 & 3 & -3 & 20 & -8 & 57 & 2 & 15 & -16 & 27 & 13 \\
\hline Vd & 62 & 5 & 7 & -4 & 17 & 11 & 14 & -14 & 67 & 12 & 16 & -15 & 17 & 3 \\
\hline Md & 88 & 31 & 1 & -10 & 3 & -3 & 8 & -20 & 63 & 8 & 28 & -3 & 10 & -4 \\
\hline $\mathrm{Me}$ & 81 & 24 & 2 & -9 & 11 & 5 & 6 & -22 & 55 & 0 & 18 & -13 & 31 & 17 \\
\hline Эк & 67 & 10 & 3 & -8 & 8 & 2 & 22 & -6 & 62 & 7 & 17 & -14 & 25 & 11 \\
\hline $\mathrm{HCP}_{05}$ & 4 & & 3 & & 2 & & 3 & & 3 & & 2 & & 4 & \\
\hline
\end{tabular}




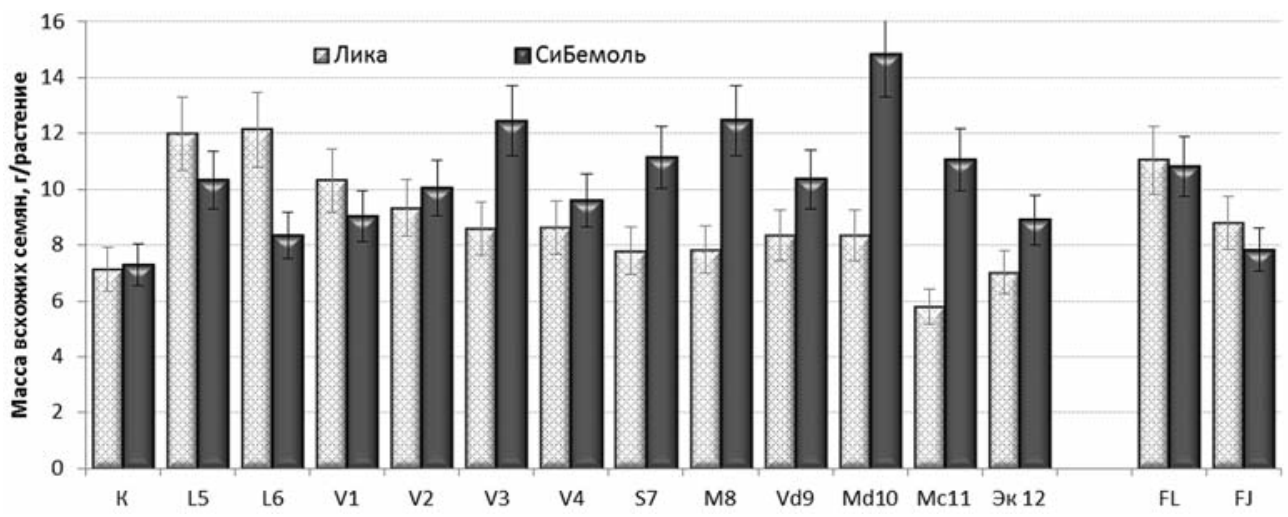

В целом, обработка растений фасоли овощной регуляторами роста растительного происхождения за счет их иммуномодулирующей и стимулирующей активности способствовала увеличению выхода массы всхожих семян с растения относительно контроля, исходя из средней продуктивности растений в каждом варианте опыта (рис. 2).

Бемоль (табл.5). Доля всхожих семян увеличилась на 931\%, и в основном за счет снижения в структуре урожая зараженных и непрорастающих семян, процент которых в контроле составил $11 \%$ и $28 \%$ соответственно. Доля невыполненных семян у сорта Си Бемоль была относительно невысока (2-12\%), в отличие от сорта Лика, у которого фракция таких семян во многих вариантах превысила 20\%. По-видимому, это связано с высокой отзывчивостью сорта Лика на действие экзогенных регуляторов роста, способствующее увеличению завязываемости бобов в узлах более высоких порядков, семена которых не успели достичь биологической спелости.

Обработка растений водными растворами фитопрепаратов у обоих сортов привела к существенному снижению в структуре урожая доли зараженных и увеличению доли всхожих семян - на 3-26\% относительно контроля. Исключение составили только варианты с применением местима (Me), скрофуларизида (Sn) и меланпирозида (Mn), где всхожесть семян осталась на уровне контроля. Интересно отметить, что у сорта Лика, более восприимчивого к бактериозам и фузариозу, из стандартов эффективнее оказался фитолавин, тогда как у более восприимчивого к ВОМФ сорта Си Бемоль, - фармайод, повысивших всхожесть относительно контроля на $26 \%$ и $30 \%$ соответственно. Среди испытанных препаратов на уровне лучшего стандарта сработали молдстим (Md) - на сорте Си Бемоль и генистифализид $(\mathrm{Lg})$ - на сорте Лика. B целом, обработка растений фасоли овощной регуляторами роста растительного происхождения за счет их иммуномодулирующей и стимулирующей активности способствовала увеличению выхода массы всхожих семян с растения относительно контроля, исходя из средней продуктивности растений в каждом варианте опыта (рис. 2).

Наибольшую совокупную эффективность на сорте Лика проявили ириоидные гликозиды из Linaria genistifolia и сумма иридоидов и флавоноидов из Linaria vulgaris, a на сорте Си Бемоль - препарат молдстим на основе стероидного гликозида фуростанолового ряда капсикозида из Capsicum annuum. Их биологическая эффективность по данному показателю составила более 70\%, тогда как среди стандартов в среднем она не превышала $50 \%$ - у Фитолавина (FL) и $25 \%$ - у Фармайода (FJ) на обоих сортах

\section{Заключение}

В современной практике растениеводства все большее внимание уделяется разработке принципиально новых способов повышения иммунных свойств растений с помощью биологически активных природных веществ, заключающихся не в полном уничтожении фитопатогенных организмов, а в регуляции взаимоотношения их с растением-хозяином. к таким соединениям относятся фиторегуляторы гормонального и негормонального типа на основе вторичных метаболитов высших растений с широким спектром действия [27, 29, 30, 35].

В связи с развитием данного направления следует учитывать избирательность их физиологической активности, в том числе и непосредственно на возбудителей болезней. Так, в опытах in vitro показано выраженное фунгицидное действие на ряд возбудителей микозов растений генистифолиозида - экстракта из надземной части Linaria genistifolia, содержащий сумму ириоидных гликозидов (5-О-аллози-

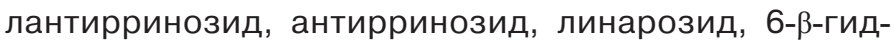
роксиантиррид). Менее, но также активен в этом плане вероофицилизид - экстракт из надземной части Veronica officinalis, в состав которого входят четыре флавоноидных гликозида (6-гидроксилютеолин-7-О-глюкопиранозид, цинарозид, апигенин-7-Оглюкопиранозид, апигенин -7-О-глюкуронид) [37].

Наиболее полно в этом плане изучено действие большого класса стероидных гликозидов высших растений и выявлено более высокая фунгицидная и антибактериальная активность спираностоноловых, чем фуростаноловых гликозидов в условиях in vitro [31]. Однако неактивные фуростаноловые гликозиды при внедрении в растительную или клетку патогена под действием $\beta$-гликозидаз образуют активную спиростаноловую форму стероидных гликозидов, которые ингибируют развитие грибов или других патогенных микроорганизмов. Их токсическое действие связывают со способностью к комплексообразованию со стеринами, белками и фосфолипидами мембран, вызывая деструкцию клеточных мембран микроорганизмов, увеличение ионной проницаемости, а также нарушение процессов окислительного фосфорилирования, влияя на АТФ-азную активность митохондриальных мембран. Перестройка стероидного биосинтеза под влиянием фуростаноловых гликозидов вызыва- 
ет переключение путей биосинтеза со стеринов на другие изопреноиды, токсичные для различных фитопатогенов, в том числе и фитогельминтов [31].

Стероидные гликозиды, изменяя метаболизм зараженного растения, способны индуцировать устойчивость и к вирусной инфекции, за счет образования новых белков и повышения активности фермента PHК-азы, вызывающего деполимеризацию РНК вируса. Кроме того, обработка зараженных растений стероидными гликозидами способствует восстановлению ультраструктурной организации фотосинтетического аппарата клетки, нарушенного вирусной инфекцией. В присутствии фуростаноловых гликозидов, проявляющих высокую антиоксидантную активность, создаются условия для сдвига метаболизма каротиноидов в сторону образования пигментов виолаксантинового цикла (зеаксантина, антераксантина и виолаксантина, играющих защитную роль в стабилизации фотосинтетического аппарата, что особенно важно в любых стрессовых условиях $[31,32,37]$.

Обработка растений экзогенными фиторегуляторами на основе вторичных метаболитов высших растений воздействует как на патоген, так и на растение-хозяина. Стимуляция роста и фитоиммунитета растений позволяет рассматривать эти соединения как природные адаптогены, как естественный фактор защиты растений от фитопатогенов и других стрессоров, способствуя более полной реализации их репродуктивного потенциала. Однако наблюдаемые эффекты от применения фитопрепаратов различной природы не всегда совпадают даже у разных сортов одной культуры и имеют разную степень выраженности в отношении отдельных хозяйственно важных признаков, свидетельствуя о высокой сортоспецифичности действия.

\section{Об авторах: \\ Елена Георгиевна Козарь - кандидат с.-х. наук, ведущий научный сотрудник лаборатории иммунитета и защиты растений \\ kozar_eg@mail.ru, https://orcid.org/0000-0002-1319-5631 \\ Ирина̄ Александровна Енгалычева - зав. лаборатории иммунитета и защиты растении, engirina1980@mail.ru, https://orcid.org/0000-0003- 4843-111x \\ Александр Александрович Антошкин - кандидат с.-х. наук, старший научный сотрудник лаборатории селекции и семеноводства бобовых культур, aa_antoshkin@mail.ru, https://orcid.org/0000-0002-3534-8417 Наталья Евгеньевна Мащенко - кандидат химических наук, ведущий научный сотрудник лаборатории биологически активных веществ, mne4747@mail.ru, https://orcid.org/0000-0003-1869-4357}

\section{- Литература}

1. FAOSTAT - Food and Agriculture Organization website: http://faostat.fao.org

2. De Ron A.M., 2015 De Ron A.M. (Ed.). Grain Legumes. In: Handbook of Plant Breeding/Spain, Pontevedra, 2015 (doi:10.1007/978-1-4939-2797-5)

3. Broughton W.J., Hernandez G., Blair M., Beebe S., Gepts P., Vanderleyden J. Beans (Phaseolus spp.) - model food legumes. Plant and Soil. 2003:(252):55-128.

4. Вишнякова М.А., Булынцев С.В., Бурляева М.О., Буравцева Т.В., Егорова Г.П. Семенова Е.В., Сеферова И.В. Исходный материал для селекции овощных бобовых культур в коллекции ВИР. Овощи России. 2013;(1):16-25. https://doi.org/10.18619/2072 9146-2013-1-16-25

5. Солдатенко А.В., Разин А.Ф., Пивоваров В.Ф., Шатилов М.В., Иванова М.И., Россинская О.В., Разин О.А. Овощи в системе обеспечения продовольственной безопасности России. Овощи России. 2019;(2):9-15. https://doi.org/10.18619/2072-9146-2019-2-9 155

6. Barampama Z., Simard E.R. Nutrient composition, protein quality, and negative elements of certain beans (Phaseolus vulgaris L.) grown in Burundi. Food Chem. 1993:(47):159/167

7. Буравцева Т.В., Никишкина М.А. Каталог мировой коллекции ВИР. Вып. 745. Фасоль. Характеристика образцов по активности ингибиторов трипсина, содержанию белка в семенах и другим хозяйственно ценным признакам (под ред. Вишняковой М.А.). СПб. 2004. C.21.

8. Горовая Т.К., Сайко О.Ю. Изменчивость биохимического состава зелёных бобов фасо-
В наших исследованиях наиболее выраженное иммуномодулирующее действие на устойчивость растений фасоли овощной к возбудителям различной этиологии проявили фитопрепараты на основе фуростаноловых стероидных гликозидов - молдстим и местим, при этом, в отличие от других БАВов, отзывчивость сортов на обработку этими препаратами была сопоставима. В отношении семенной продуктивности растений, практически все испытанные фитопрепараты проявили стимулирующее действие, за исключением официнального препарата местим. Обработка местимом оказала отрицательное влияние на общую семенную продуктивность растений фасоли, особенно на отзывчивом сорте Лика. Вероятно, эту проблему возможно решить путем подбора оптимальной концентрации этого препарата, в которой он, проявляя высокое иммуномодулирующее влияние на устойчивость к болезням, не оказывает фитотоксического действия на растения этого сорта.

Включение новых элементов в сортовые технологии семеноводства должно способствовать не только повышению продуктивности растений, но и улучшению посевных качеств семенного материала, способствуя увеличению общего выхода посевных единиц (семян). С этой точки зрения, на сорте Лика наибольшую совокупную эффективность проявили фитопрепараты генистифализид и линарозид на основе ириоидных гликозидов и флавоноидов, полученные из растений семейства Linaria. На сорте Си Бемоль препарат молдстим на основе стероидного гликозида фуростанолового ряда капсикозида из Capsicum annuum.

Таким образом, природные биорегуляторы растительного происхождения можно рассматривать не только как составную часть системы защиты, но и повышения продуктивности растений фасоли овощной.

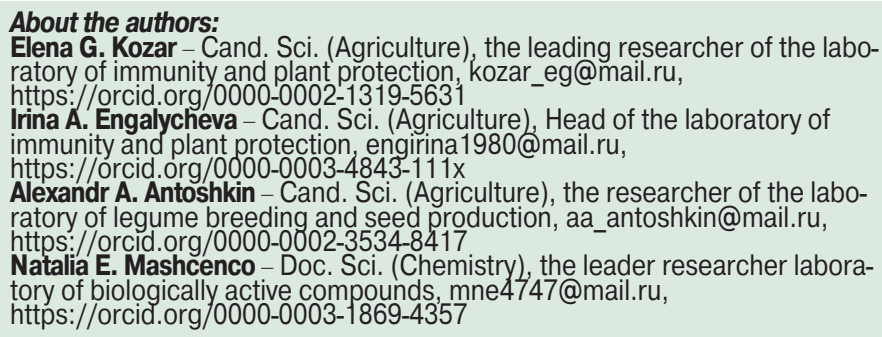

ли обыкновенной. Овощи России. 2014;(1):48-52. https://doi.org/10.18619/2072-9146-2014 1-48-52

9. Пивоваров В.Ф., Пронина Е.П. Основные направления и результаты селекции и семеноводства овощных бобовых культур во ВНИИССОК. Овощи России. 2013;(1):4-11. https://doi.org/10.18619/2072-9146-2013-1-4-11

10. Антон Ш., Смирнова А.М., Антошкин А.А. Оценка коллекционных образцов фрасоли овощной по хозяйственно ценным признакам в условиях Московской области. Овощи России. 2018;(5):43-46. https://doi.org/10.18619/2072-9146-2018-5-43-46

11. Антошкин А.А., Деговцов В.Е., Пронина Е.П., Антошкина М.С. Спаржевые сорта фасоли овощной селекции ВНИИССОК и их пригодность для переработки. Зернобобовые и крупяные культуры. 2014;4(12):86-89.

12. Dobrutskaya E.G., Musaev F.B., Miroshnikova M.P. Suitability of the environment at VNIISSOK for selection and seed production of vegetable beans. Collection of scientific papers VNIISSOK. 2009:(43):65-68

13. Филимонова Ю.А. Оценка коллекционных образцов фасоли овощной по химическому составу в условиях Западной предгорной зоны Северного Кавказа. Гавриш. 2006:(5):17-19.

14. Государственный реестр селекционных достижений, допущенных к использованию. Т.1. «Сорта растений» (осициальное издание). М.: ФГБНУ «Росинформагротех» 2019. $516 \mathrm{c}$.

15. Ракина М.С. Биоресурсный потенциал зернобобовых культур из коллекции мирового генофонда Всероссийского научно-исследовательского института растениеводства им. Н.И. Вавилова. Новосибирск, 2011 
16. Лазарева Е.К. Морфобиологические и биохимические особенности сортообразцов фасоли обыкновенной (Phaseolus vulgaris L.) в условиях Орловской области. Автореф. канд. дисс. Рамонь, 2006

17. Плетнева М.М. Оценка образцов фасоли обыкновенной по хозяйственно-ценным признакам и качеству зерна для селекции в южной лесостепи Западной Сибири. Автореф. Канд. Дисс. Омск, 2019

18. Гнутова Р.В. Вирусные инфекции овощных бобовых культур и сои на Дальнем Востоке. Защита и карантин растений. 2013;(1):14-17.

19. Игнатов А.Н., Челидзе Г.Г., Воробьева К.С. Риски распространения в РФ новых вирусных и бактериальных болезней овощных культур через предприятия защищенного грунта. Картосфель и овощи. 2019:(4):18-21. DOI: 10.25630/PAV.2019.84.71.002

20. Тимина Л.Т., Пронина Е.П., Антошкин А.А. Бактериозы фасоли: распространение и меры борьбы. Картофрель и овощи. 2012;(7):26.

21. Тимина Л.Т., Пронина Е.П., Антошкин А.А. Устойчивость фасоли овощной к бактериальным пятнистостям. Защита и карантин растений. 2013;(12):20-22.

22. Енгалычева И.А., Плешакова Т.И., Гапека А.В., Тимина Л.Т. Мониторинг особо опасных вирусных заболеваний культур семейства Бобовые в условиях Московской области В сб.: Повышение эфффективности сельскохозяйственной науки в современных условиях материалы международной научно-практической конференции молодых ученых и специалистов. Краснодар, 2015: 41-44.

23. Соколова Л.М. Анализ видового разнообразия грибов из рода Fusarium. Аграрная наука. 2019;(1):118-122. https://doi.org/10.32634/0869-8155-2019-326-1-118-122 24. Волынец А.П., Шуканов В.П., Полянская С.Н. Стероидные гликозиды - новые фиторегуляторы гормонального типа. 2003: 134.

25. Алексеева К.Л. Биорегуляторы в технологиях выращивания и защиты овощных культур. Сборник трудов: НАН Беларусь. Минск, 2008;(15):96-103

26. Козлов И.И. Применение биологически активных веществ при выращивании лука репчатого. Аграрный вестник Урала. 2011;(3):69-70.

27. Васильева И.С., Пасешниченко В.А. Стероидные гликозиды растений и культуры клеток диоскореи, их метаболизм и биологическая активность. Успехи биологической химии. 2000; (40):153-204.

28. Балашова Н.Н., Жученко А.А., Пивоваров В.Ф., Балашова И.Т., Козарь Е.Г. Беспалько А.В., Пышная О.Н., Кинтя П.К., Лупашку Г.А., Мащенко Н.Е., Швец С.А. Бобейкэ В.А. Регуляция устойчивости фитопатосистем с помощью вторичных метаболитов растений. Сельскохозяйственная биология. 2004;39(1):3-16

29. Mascenco N., Gumaniuc A., Borovskaia A., Botnari V., Vasilachi I. Procedeu de tratare a semintelor de castraveți înainte de semănat. Brevet MD 901. 2015

30. Шуканов В.П., Полякова Н.В., Корытько Л.А., Мащенко Н.Е., Боровская А.Д. Новые биорегуляторы гликозидной природы для индуцирования болезнеустойчивости зерновых культур. Materialele conferinței stiintifice internationale (Ediția a V-a) «Genetica, fiziologia si ameliorarea plantelor». Chisinău. 2014;(1):445-449.

31. Козарь Е.Г., Ветрова С.Ӓ., Федорова М.И., Мащенко Н.Е. Действие экзогенных стероидных гликозидов на проявление инбредной депрессии растений свёкпы стоповой в условиях защищенного грунта. Овощи России. 2017;(3):16-22. https://doi.org/10.18619/2072-9146-2017-3-16-22

32. Балашова И.Т., Козарь Е.Г., Бухаров А.Ф., Бухарова А.Р., Мащенко Н.Е., Фомина А.А. Роль стероидных гликозидов в экологизации семеноводства овощных культур. Успехи современной науки. 2017;1(9):83-91.

33. Mashcenko N., Gurev A., Lupascu G., Gorincioi E.. Iridoid Glycosides from Linaria genistifolia (L.) MILL. in Biological Control of Soil-Borne Fungal Pathogens of Wheat and Some Structure. Chemistry Journal of Moldova. 2015,10(1):57-64

34. Mashcenko N., Kintia P., Gurev A., Marchenko A., Bassarello C., Piacente S., Pizza C. Glycosides from Linaria vulgaris Mill. Chem.J.Mold. 2008,4 (2):99-101.

35. Ahmad M., Muhammad N., Mehjabeen, n.Jahan, Ahmad M., Obaidullah, Qureshi M., Umar Jan S.. Spasmolytic effect of Scrophularia nodosa extract on isolated rabbit intestine Pak.J.Pharm. Sci., January 2012;25(1):267-275.

36. Галишевская E. Петриченко В.M. Иридоидные соединения растений рода марьянник. Вестник Пермского государственной фармацевтической академии. 2007; (2):223-229

37. Гвазава Л.Н., Киколадзе В.С. Оробанхозид и фллавоноиды из Verbascum и Verbascum densiflorum. Химия природных соединений. 2011:(6):864-865.

38. Методические указания и рекомендации по селекции и семеноводству овощных бобовых и капустных культур. М: ВНИИССОК. 2001.

39. Методические указания по регистрационным испытаниям фунгицидов в сельском Хозяйстве. СПБ. 2005

40. Лазарев А.М. Бактериозы зернобобовых культур и меры борьбы с ними (методические рекомендации). СПБ: ВИЗР, 2006.

41. Методика оценки гороха на устойчивость к фузариозным корневым гнилям. СПб, 2002.

42. Буданова В.И, Лагутина Л.В., Корнейчук В. и др. Широкий унифицированный классификатор СЭВ и международный кпассификатор СЭВ культурных видов рода Phaseolus ᄂ. Л.: ВИР. 1984

43. ГОСТ 12042-80 Межгосударственный стандарт «семена сельскохозяйственных культур. Методы определения массы 1000 семян».

\section{- References}

1. FAOSTAT - Food and Agriculture Organization website: http://faostat.fao.org

2. De Ron A.M., 2015 De Ron A.M. (Ed.). Grain Legumes. In: Handbook of Plant Breeding/Spain. Pontevedra, 2015 (doi:10.1007/978-1-4939-2797-5)

3. Broughton W.J., Hernandez G., Blair M., Beebe S., Gepts P., Vanderleyden J. Beans (Phaseolus spp.) - model food legumes. Plant and Soil. 2003;(252):55-128.

4. Vishnjakova M.A., Bulintsev S.V., Burlyaeva M.O., Buravtseva T.V., Egorova G.P Semenova E.V., Seferova I.V. The initial material for grain legumes breeding in the collection of VIR. Vegetable crops of Russia. 2013;(1):16-25. (In Russ.) https://doi.org/10.18619/2072-91462013-1-16-25

5. Soldatenko A.V., Pivovarov V.F., Razin A.F., Shatilov M.V., Ivanova M.I., Rossinskaya O.V., Razin O.A. Vegetables in the system of ensuring food security of russia. Vegetable crops of Russia. 2019;(2):9-15. (In Russ.) https://doi.org/10.18619/2072-9146-2019-2-9-15

6. Barampama Z., Simard E.R. Nutrient composition, protein quality, and negative elements of certain beans (Phaseolus vulgaris L.) grown in Burundi. Food Chem. 1993;(47):159/167.

7. Buravtseva T.V., Nikishkina M.A. Catalog of the VIR world collection. Issue 745. Beans. Characterization of samples by activity of trypsin inhibitors, protein content in seeds and other economically valuable traits (ed. by M.A. Vishnyakova). SPb. 2004. P. 21. (In Russ.)

8. Gorovaya T.K., Sayko O.Yu. Variability of the biochemical composition of green^podded of common bean. Vegetable crops of Russia. 2014;(1):48-52. (In Russ.) https://doi.org/10.18619/2072-9146-2014-1-48-52

9. Pivovarov V.F. Pronina E.P. Main directions and results of vegetable breeding and seed production of vegetable crops of legumes in VNIISSOK Vegetable crops of Russia. 2013:(1):4-11. (In Russ.) https://doi.org/10.18619/2072-9146-2013-1-4-11

10. Anton S., Smirnova A.M., Antoshkin A.A. Evaluation of collection samples of vegetable beans (Phaseolus vulgaris L.) for economically valuable grounds in the conditions of the Moscow region. Vegetable crops of Russia. 2018;(5):43-46. (In Russ.) https://doi.org/10.18619/2072-9146-2018-5-43-46

11. Antoshkin A.A.1, Degovtsov V.E.1, Pronina E.P.1, Antoshkina M.S. Varieties of black-eyed vegetable pea of VNIISSOK"s breeding and it's processability. Legumes and groat crops. 2014:4(12):86-89. (In Russ.)

12. Dobrutskaya E.G. Musaev F.B. Miroshnikova M.P. Suitability of the environment at VNIISSOK for selection and seed production of vegetable beans. Collection of scientific papers VNIISSOK. 2009;(43):65-68. (In Russ.)

13. Filimonova Yu.A. Evaluation of the collection of vegetable bean samples by chemical composition in the conditions of the Western foothill zone of the North Caucasus. Gavrish 2006:(5):17-19. (In Russ.)

14. State Register of Breeding Achievements Approved for Use. Vol. 1. "Plant Varieties" (offcial publication). M.: FGBNU "Rosinformagrotech" 2019. 516 p. (In Russ.)

15. Rakina M.S. Bioresource potential of leguminous crops from the collection of the world gene pool of the All-Russian Research Institute of Plant Industry named after V.I. N.I. Vavilov. Novosibirsk, 2011. (In Russ.)

16. Lazareva E.K. Morphobiological and biochemical characteristics of common bean varieties (Phaseolus vulgaris L.) in the conditions of the Oryol region. 2006.

17. Pletneva M.M. Evaluation of common bean samples for economically valuable traits and grain quality for breeding in the southern forest-steppe of Western Siberia. Omsk, 2019.

18. Gnutova R.V. Virus infections of the vegetable legume crops and soybean in the Far East. Plant protection and quarantine. 2013;(1):14-17. (In Russ.)

19. Ignatov A.N., Chelidze G.G., Vorobyova K.S. Risks of spreading of new viral and bacterial diseases of vegetable crops in the Russian Federation through greenhouse production. Potato and vegetables. 2019;(4):18-21. DOI: 10.25630/PAV.2019.84.71.002

20. Timina L.T., Pronina E.P., Antoshkin A.A. Bean bacteriosis: distribution and control measures. Potato and vegetables. 2012;(7):26. (In Russ.)

21. Timina L.T., Pronina E.P., Antoshkin A.A. Resistance of green beans to the bacterial blights. Plant protection and quarantine. 2013;(12):20-22. (In Russ.)

22. Engalycheva I.A., Pleshakova T.I., Gapeka A.V., Timina L.T. Monitoring of especially dangerous viral diseases of legumes in the Moscow region. In collection: Increasing the efficiency of agricultural science in modern conditions, materials of the international scientific and practcal conference of young scientists and specialists. Krasnodar, 2015. P.41-44. (In Russ.)

23. Sokolova L.M. Analysis of species diversity of fungi of the genus Fusarium. Agrarian science. 2019; (1):118-122. (In Russ.) https://doi.org/10.32634/0869-8155-2019-326-1-118-122 24. Volynets A.P., Shukanov V.P., Polyanskaya S.N. Steroid glycosides are new hormonal phytoregulators. 2003. 134 p. (In Russ.)

25. Alekseeva K.L. Bioregulators in the technologies of growing and protecting vegetable crops. Collection of works: NAS Belarus. Minsk, 2008:(15):96-103. (In Russ.)

26. Kozlov I.I., Kunavin G.A. Application of biologically active substances at cultivation of onions napiform. Agrarian bulletin of the Urals. 2011; (3):69-70. (In Russ.)

27. Vasilyeva I.S., Paseshnichenko V.A. Steroidal glycosides of plants and cell cultures of dioscorea, their metabolism and biological activity. Advances in biological chemistry. 2000; (40):153-204. (In Russ.)

28. Balashova N.N., Zhuchenko A.A., Pivovarov B.F., Balashova I.T., Kozar' E.G., Bespal'ko A.V., Pyshnaya O.N., Kintya P.K., Lupashku G.A., Mashchenko N.E., Shvets S.A., Bobeike V.A. Regulation of tolerance of phytopathosystems with help of second metabolite of plants. Agricultural biology. 2004:39(1):3-16. (In Russ.)

29. Mașcenco N., Gumaniuc A., Borovskaia A., Botnari V., Vasilachi I. Procedeu de tratare a seminţelor de castraveți înainte de semănat. Brevet MD 901. 2015

30. Shukanov V.P., Polyakova, N.V., Korytko L.A., Mashchenko N.E., Borovskaya A.D. New bioregulators of a glycosidic nature for inducing disease resistance in cereal crops. Materialele conferinței științifice internationale (Ediția a V-a) «Genetica, fiziologia ș ameliorarea plantelor»». Ćhișinău. 2014;(1):445-449

31. Kozar E.G., Vetrova S.A., Fedorova M.I., Mashenko N.E. An action of exogenous steroidal glycoside on exhibition of inbreeding depression in red beet plants under protected cultivation technology. Vegetable crops of Russia. 2017:(3):16-22. (In Russ.) https://doi.org/10.18619/2072-9146-2017-3-16-22

32. Balashova I.T., Cozar E.G., Bukharov A.F., Bukharova A.R., Maschenko N.E., Fomina A.A. Role of steroid glycosides in the ecologization of vegetable seed production. Advances in modern science. 2017:1(9):83-91. (In Russ.)

33. Mashcenko N., Gurev A., Lupascu G., Gorincioi E.. Iridoid Glycosides from Linaria genistifolia (L.) MILL. in Biological Control of Soil-Borne Fungal Pathogens of Wheat and Some Structure. Chemistry Journal of Moldova. 2015;10(1):57-64

34. Mashcenko N. Kintia P. Gurev A. Marchenko A., Bassarello C. Piacente S., Pizza C. Glycosides from Linaria vulgaris Mill. Chem.J.Mold. 2008:4(2):99-101.

35. Ahmad M., Muhammad N., Mehjabeen, n. Jahan, Ahmad M., Obaidullah, Qureshi M. Umar Jan S. Spasmolytic effect of Scrophularia nodosa extract on isolated rabbit intestine. Pak.J.Pharm. Sci. January 2012;25(1):267-275

36. Galishevskaya E.E., Petrichenko V.M. Iridoid compounds of plants of the genus mariannik. Bulletin of the Perm State Pharmaceutical Academy. 2007;(2):223-229. (In Russ.)

37. Gvazava L.N., Kikoladze V.S. Orobanchoid and flavonoids from Verbascum and Verbascum densiflorum.. Chemistry of natural compounds. 2011;(6):864-865. (In Russ.) 38. Methodical instructions and recommendations for selection and seed production of vegetable legumes and cabbage crops. M: VNIISSOK. 2001. (In Russ.)

39. Methodical instructions for registration tests of fungicides in agriculture. SPb. 2005. (In Russ.) 40. Lazarev A.M. Legume bacteriosis and control measures (guidelines). SPB: VIZR, 2006. (In Russ.)

41. Methodology for evaluating peas for resistance to Fusarium root rot. SPb, 2002. (In Russ.) 42. Budanova V.I. Lagutina L.V., Korneichuk V. et al. Wide unified CMEA classifier and international CMEA classifier of cultivated species of the genus Phaseolus L. L.: VIR. 1984. 37 p. (In Russ.)

43. GOST 12042-80 Interstate standard "Seeds of agricultural crops. Methods for determining the mass of 1000 seeds." (In Russ.) 